\title{
Galium divaricatum Pourr. ex Lam. (Rubiaceae) - a new species for the flora of Ukraine
}

\author{
Pavel Novák ${ }^{1^{*}}$, Dominik Zukal ${ }^{1}$ \\ ${ }^{1}$ Department of Botany and Zoology, Faculty of Science, Masaryk University, Kotlářská 2, CZ 611-37 Brno, Czech \\ Republic
}

\begin{abstract}
Galium divaricatum Pourr. ex Lam. is an annual plant species occurring mainly in dry grasslands. The centre of its distribution range is situated in the Mediterranean region, while in Central Europe it has been known only from a few isolated sites in Slovakia and Hungary. In 2016 we discovered this species in open dry grassland of the class Sedo-Scleranthetea on the upper edge of a basaltic andesite quarry near the village of Siltse, Irshavskyi District, Zakarpatska Region, as a new species for the Ukrainian flora. The site is situated in the transitional region between the Pannonian Basin and the Eastern Carpathians. The new locality represents the northernmost recent occurrence of this species.
\end{abstract}

Keywords: Carpathians, Mediterranean floral element, Pannonian Basin, phytogeography, Sedo-Scleranthetea, Zakarpatska Region

\section{Introduction}

Galium divaricatum Pourr. ex Lam. is a member of the Galium parisiense group, which contains annual species of open dry habitats. Besides G. divaricatum, two other species of this group occur in Central Europe, G. parisiense and G. tenuissimum. All three of these species are sparsely distributed and occur mainly in the Pannonian Basin and in the warm foothills of the Carpathians (Paucă 1961, Řehořek 2007, Bartha et al. 2015). Of this group, only G. tenuissimum has been known in Ukraine (Mosyakin and Fedoronchuk 1999), where it is limited to Crimea (Yena 2012). This paper focuses on G. divaricatum which was discovered in the Zakarpatska Region (W Ukraine) as a new plant for the Ukrainian flora in June 2016.

Galium divaricatum was described in France and is considered to be a Mediterranean element of the European flora. The centre of its distribution range is in the Near East and Southern Europe. It is distributed in the Eastern Mediterranean Basin including Lebanon, Syria, Turkey and Cyprus and in the whole of the Balkan (e.g. Paucă 1961, Ehrendorfer and Schönbeck-Temesy 1982) and Italian (Pignatti 1982) peninsulas. It is also known in southern France (Royer and Tison 2014). The westernmost localities of its distribution range are located in the Iberian Peninsula (Ortega Olivencia and Devesa 2007). G. divaricatum is also reported as a neophyte in various regions of the world (Lipscomb and Nesom 2007). There are several records of G. divaricatum in Central Europe (Fig. 1). It is known only in the south-eastern

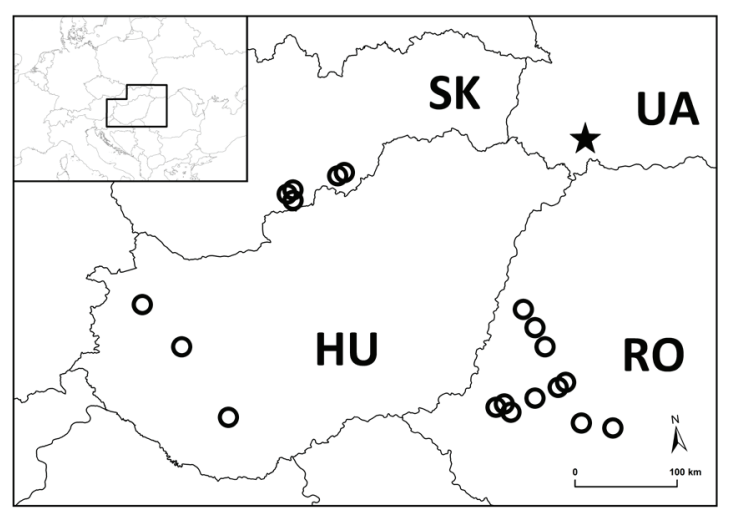

Fig. 1. Distribution map of Galium divaricatum in Central Europe based on literature records (circles) and the new finding in Ukraine (asterisk). 
part of this region. Its northern distribution limit has been assumed to occur in southern Slovakia (Řehořek 2007) and western Hungary (Bartha et al. 2015). There are historical records from volcanic bedrock at the southern edge of the Western Carpathians in Slovakia. It has been reported there in five sites near the villages of Blhovce, Filakovské Kováče,

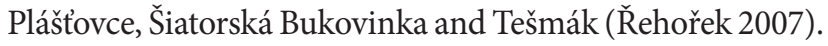
The second site represents its northernmost occurrence in its native distribution range $\left(48^{\circ} 17^{\prime} \mathrm{N}\right)$. However, it is currently supposed to be an extinct species of the Slovak flora (Eliás et al. 2015). There are also several localities mentioned in Romanian Transylvania (Paucă 1961, Pop and Hodişan 1964). Nevertheless, it has not been known in Ukraine until now (cf. Mosyakin and Fedoronchuk 1999), when it was found in the western part of the country (Zakarpatska Region). The Zakarpatska Region has been investigated by botanists for more than one hundred years. However, their research (e.g. Thaisz 1911, Stojko et al. 1982) has focused mainly on the higher altitudes of this area and on a few sites with thermophilous vegetation in the volcanic Carpathian foothills (Fodor 1974, Votkalchuk 2012). In contrast, the flora of the flat lowland part of the region and the lower volcanic hills has not been sufficiently studied, as is reflected by several recent findings of new vascular plant species in this area (e.g. Felbaba-Klushyna 2015).

G. divaricatum prefers open nutrient-poor dry grassland vegetation developed on substrates of various $\mathrm{pH}$ (Paucă 1961, Royer and Tison 2014). To our knowledge, the only phytosociological relevé with $G$. divaricatum recorded in Central Europe was published in the above mentioned paper from Romanian Transylvania (Pop and Hodişan 1964). It occurs there in dry grassland dominated by Festuca valesiaca with the occurrence of several annual species indicating disturbance. This grassland probably belongs to the alliance Festucion valesiaceae Klika 1931.

The aim of this study is to report the occurrence of $\mathrm{G}$. divaricatum in Ukraine, to describe the new site and to put this finding into a broader phytogeographical context.

\section{Materials and methods}

The Zakarpatska Region is located in the transitional zone between the Pannonian and Carpathian biogeographical regions (Fekete et al. 2016) which makes its position quite unusual for Ukraine. Its low-altitudinal south-western part, including the locality of $G$. divaricatum, belongs to the distinctive Pannonian Province of the forest-steppe geobotanical zone (Didukh and Shelyag-Sosonko 2007). The mean annual temperature of the surroundings of the G. divaricatum site is around $9{ }^{\circ} \mathrm{C}$ and annual precipitation is around 800 $\mathrm{mm}$ (Andó 1999). The climate supports the development of forest vegetation on zonal sites with deep soils on flysch or loess. Therefore, remnants of dry grasslands are limited to small patches with shallow dry soils situated on sunny slopes of the volcanic hills that are scattered in the lower part of the region (Fodor 1974).

G. divaricatum was determined using identification literature (e.g. Paucă 1961, Ehrendorfer and Schönbeck-Temesy 1982, Royer and Tison 2014) and herbarium vouchers stored in the Herbarium of Masaryk University, Brno, Czech Republic (BRNU). The determination was confirmed by an expert in the G. parisiense group Vladimír Řehořek (Masaryk University, Brno). The herbarium specimens of G. divaricatum from the new site have been deposited in BRNU. The nomenclature of plants in the article follows Euro+Med PlantBase (2006-).

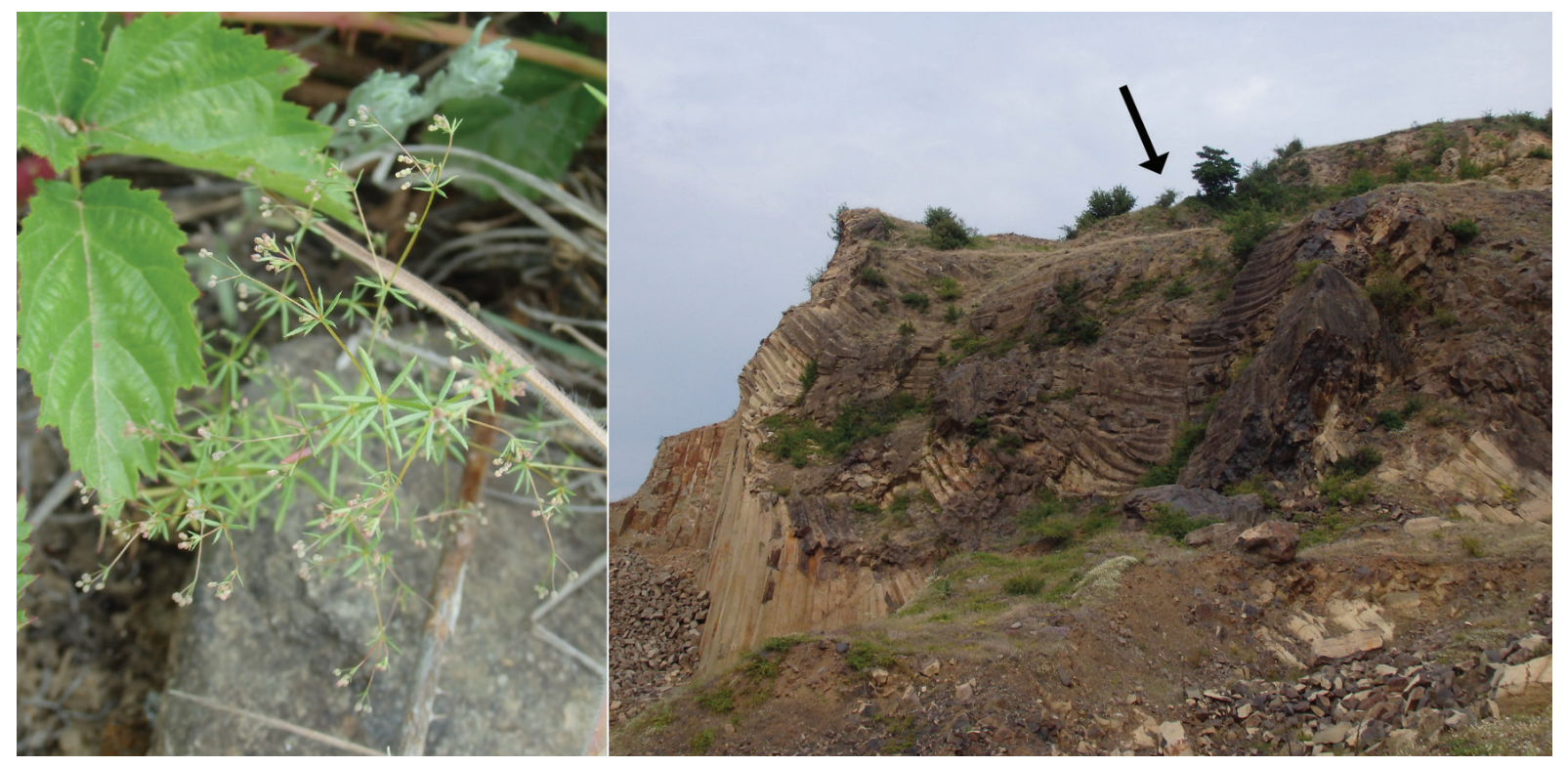

Fig. 2. Galium divaricatum (left) and its site in a basaltic andesite quarry (right) above the village of Siltse near Irshava taken from the south. The place in which the species occurs is indicated by an arrow (photo P. Novák, 10 June 2016). 


\section{Results and discussion}

During phytosociological research into dry grassland vegetation near the village of Siltse (Irshavskyi District) on 10 June 2016, we discovered several dozen individuals of an annual plant species belonging to the Galium parisiense group. It was subsequently recognised as $G$. divaricatum, a new species for the Ukrainian flora (cf. Mosyakin and Fedoronchuk 1999).

The new locality of $G$. divaricatum is a basaltic andesite quarry on a south-facing slope of a hill above the village of Siltse (Fig. 2). The hill is part of the Vihorlat-Gutâi Volcanic Belt (Andó 1999). G. divaricatum grows on the upper edge of the quarry near a footpath to the hilltop $\left(48^{\circ} 17^{\prime} 36.1^{\prime \prime} \mathrm{N}\right.$, $22^{\circ} 59^{\prime} 17.6^{\prime \prime} \mathrm{E}$ ) at an altitude of $200 \mathrm{~m}$. It was recorded in open grassland containing mainly thermophilous acidotolerant therophytes such as Anthemis arvensis, Arenaria serpyllifolia, Bromus hordeaceus, Filago arvensis, Polycnemum arvense, Scleranthus annuus and Vulpia myuros. Some perennial species occurred there as well, e.g. Centaurea stoebe, Chondrilla juncea and Rubus sp. This temporary pioneer vegetation type may be classified within the class Sedo-Scleranthetea Br.-Bl. 1955. Remnants of dry grasslands dominated by Festuca valesiaca s.l. (class Festuco-Brometea Br.-Bl. et Tüxen ex Soó 1947) were developed on the hilltop above the quarry. However, G. divaricatum was not found in this vegetation. The soil $\mathrm{pH}$ of the rocky dry grassland near the site with $G$. divaricatum was 5.6 (measured in a distilled water suspension).

The flora of the region contains many thermophilous species of both subcontinental (e.g. Koeleria glauca and Stipa pulcherrima) and sub-Mediterranean (e.g. Fraxinus or- nus, Quercus cerris, Q. pubescens, Ventenata dubia) floral elements. The co-occurrence of these elements is highly characteristic for the region (Fodor 1974) as well as for the whole of the Pannonian Basin (Fekete et al. 2016). Therefore, the new occurrence of $G$. divaricatum fits well into the character of the regional flora. Since the species is considered extinct in Slovakia (Eliáš et al. 2015), the newly discovered site in Ukraine represents the northernmost outpost of its current occurrence.

The origin of this newly discovered population is unclear. It cannot be ruled out that it was brought to the site by human activities; this hypothesis is supported by the fact that the species was not observed in the surrounding dry grassland vegetation during our field survey. Nevertheless, it is considered to be a native species both in Hungary (Bartha et al. 2015) and Slovakia ( ̌̌ehořek 2007). If the native status of the new population is confirmed, it should be classified as a critically endangered species (CR) of the Ukrainian flora with the application of criteria $\mathrm{B} 1 \mathrm{a}+\mathrm{B} 2 \mathrm{ab}$ (iii, v) of the IUCN standards (2016).

\section{Acknowledgements}

We would like to thank Vladimír Řehořek who kindly revised the herbarium specimen of Galium divaricatum from Ukraine, Kryštof Chytrý and Kateřina Píštková for taking care of the field herbarium, Martin Večeřa for preparing the distribution map, Lubov Borsukiewicz and Iveta Škodová for providing some regional literature and Milan Chytrý and Veronika Kalníková for valuable comments on the manuscript. The study was supported by the Czech Science Foundation (project 14-36079G).

\section{References}

Andó, M., 1999: Hydrogeographical features of the Upper Tisa river-system. Tiscia 4, 135-172.

Bartha, D., Király, G., Schmidt, D., Tiborcz, V., Barina, Z., Csiky, J., Jakab, G., Lesku, B., Schmotzer, A., Vidéki, R., Vojtkó, A., Zólyomi, Sz. (eds.), 2015: Distribution atlas of vascular plants of Hungary. Nyugat-magyarországi Egytem Kiadó, Sopron (in Hungarian).

Didukh, Ya. P., Shelyag-Sosonko, Yu. R., 2007: Vegetation. In: Rudenko, L. H. (ed.), National atlas of Ukraine, 440. DNVP Cartography, Kyiv.

Ehrendorfer, F., Schönbeck-Temesy, E., 1982: 6. Galium L. In: Davis, P. H. (ed.): Flora of Turkey and the East Aegean Islands, 767-849. Edinburgh University Press 7, Edinburgh.

Eliáš, P., Dítě, D., Kliment, J., Hrivnák, R., Feráková, V., 2015: Red list of ferns and flowering plants of Slovakia, $5^{\text {th }}$ edition (October 2014). Biologia 70, 218-228.

Euro+Med PlantBase, 2006-: Euro+Med PlantBase - the information resource for Euro-Mediterranean plant diversity. Retrieved January 22, 2017 from http://ww2.bgbm.org/ EuroPlusMed/.

Fekete, G., Király, G., Molnár, Z., 2016: Delineation of the Pannonian vegetation region. Community Ecology 17, 114-124.

Felbaba-Klushyna, L. M., 2015: Utricularia intermedia (Utriculariaceae), a new species for the flora of Transcarpathia. Ukrainskyi Botanichnyi Zhurnal 72, 237-240 (in Ukrainian).
Fodor, S. S., 1974: Flora of Transcarpathia. Vysha shkola, Lviv (in Ukrainian).

IUCN, 2016: IUCN Standards and Petitions Subcommittee. 2016. Guidelines for using the IUCN Red List categories and criteria. Version 12. Prepared by the Standards and Petitions Subcommittee. Retrieved February 12, 2017 from http://www. iucnredlist.org/documents/RedListGuidelines.pdf.

Lipscomb, B. L., Nesom, G. L., 2007: Galium anglicum (Rubiaceae) new for Texas and notes on the taxonomy of the G. parisiensel divaricatum complex. Journal of the Botanical Research Institute of Texas 1, 1269-1276.

Mosyakin, S. L., Fedoronchuk, N. M., 1999: Vascular plants of the Ukraine. A nomenclatural checklist. Kholodny Institute of Botany, National Academy of Sciences of the Ukraine, Kiev.

Ortega Olivencia, A., Devesa, J. A., 2007: 8. Galium L. In: Castroviejo, S. (ed.), Flora iberica: plantas vasculares de la Península Ibérica e Islas Baleares, vol. 15, Rubiaceae-Dipsacaceae, 56162. Real Jardín Botánico, Madrid.

Paucă, A., 1961: Fam. 100. Rubiaceae B. Juss. In: Săvulescu T. (ed.), Flora of the Romanian People's Republic, Vol 8, 524-589. Editura Academiei Republicii Populare Române, Bucureşti (in Romanian).

Pignatti, S., 1982: Flora d'Italia. 2. Edagricole, Bologna.

Pop, I., Hodişan, I., 1964: Floristic and vegetation studies of the Craciunesti Gorge (Hunedoara region, Brad district). Studia Universitatis Babeş-Bolyai seria Biologia 1, 7-24 (in Romanian). 
Royer, J.-M., Tison, J.-M., 2014: Galium L. In: Tison, J.-M., de Foucault, B. (eds.), Flora Gallica. Flore de France, 1020-1028. Biotope, Mèze.

Řehořek, V., 2007: G. divaricatum and Galium tenuissimum in Slovakia. Bulletin Slovenskej botanickej spoločnosti 29, 9798 (in Slovak).

Stojko, S. M., Tasjenkevych, L. O., Milkina, L. I., Malynovskyj, K. A., Tretjak, P. R., Manko, M. P. et al., 1982: Flora and vegetation of the Carpathian Reserve. Naukova Dumka, Kyiv (in Ukrainian).

Thaisz, L., 1911: Contribution to the flora of the Bereg county. Magyar Botanikai Lapok 10, 38-64 (in Hungarian).

Votkalchuk, K. A., 2012: Analysis of raritetly fitogenofond of Volcanic Carpathians. Naukovyj visnyk Uzhorodskoho universytetu Seriya Biologiya, Vypusk 33, 52-63 (in Ukrainian).

Yena, A. V., 2012: Spontaneous flora of the Crimean Peninsula. N. Orianda, Simferopol. 